Received: April, 2017

Accepted: September, 2017

ISSN $2006-6996$

\title{
GROWTH PERFORMANCE AND NUTRIENTS DIGESTIBILITY OF YANKASA SHEEP FED SUGARCANE WASTE SILAGE
}

\author{
Ashiru, R. M. ${ }^{1 *}$ Maigandi, S. A., ${ }^{2}$ Muhammad, I. R. ${ }^{3}$ and Suleiman, I. M. ${ }^{1}$ \\ ${ }^{1}$ Department of Animal Science, Kano University of Science and Technology, Wudil, Nigeria \\ ${ }^{2}$ Department of Animal Science, Usmanu Dan Fodio University, Sokoto, Nigeria \\ ${ }^{3}$ Department of Animal Science, Bayero University, Kano, Nigeria \\ *Corresponding Author: rabia@kustwudil.edu.ng, ashirurabi@gmail.com +2348037037041
}

\begin{abstract}
A Feeding trial was conducted for twelve weeks (eighty four days) to assess the performance of Yankasa sheep fed ensiled sugarcane waste (ESCW) enhanced with non - protein nitrogen (urea and poultry litter) sources and soybean meal. Sixteen (16) Yankasa rams (mean body weight 25kg士0.46; aged 8 to 15 months) were randomly allotted to the treatments groups viz; T1 (100\% SCW plus urea, unensiled) as control, T2 (100\% SCW plus urea, ensiled), T3 (75\%SCW plus $25 \%$ SBM, ensiled) and T4 (75\% SCW plus 25\% PL, ensiled) with four animals per treatment in a randomised complete block design (RCBD). The experimental diets were offered as basal diet along with clean drinking water and mineral salt lick ad-libitum, while a concentrate diet was formulated containing $16.26 \% \mathrm{CP}$ and offered at $1.5 \%$ body weight to each of the experimental animals. The results obtained indicated non significant $(P>0.05)$ differences in the treatment means of all the growth parameters evaluated however, all the values obtained for T3 and T4 were numerically higher. The digestibility of DM, CF and NFE showed that T3 and T4 gave significant/y $(P<0.05)$ higher values. In conclusion ensilage of SCW with urea, soybean meal and poultry litter enhanced its utilization by Yankasa rams, since all the animals in all the treatments gained weight. It is therefore recommended that SCW could be enhanced and ensiled with either urea (4\%:100\% SCW), SBM (25\% : 75\% SCW) or PL (25\% : 75\% SCW) for dry season sheep feeding.

Key words digestibility, sugarcane waste, non-protein nitrogen, Yankasa sheep
\end{abstract}

\section{INTRODUCTION}

In the tropics, dry season is a critical period for livestock as it is characterized by shortage of feed both in quality and quantity. Feed resources for ruminants are mainly from native rangelands, the grasses that exist during the dry season are dry and highly lignified. Adebowale (1981) stated that the dominant forage which is the natural pasture grass land grazed by ruminants in Northern Nigeria cannot meet the energy and protein requirement of the animals. Although, ruminants are less affected due to their ability to feed on poor quality forages and fibrous feeds, there is still problem of dry season feeding since feed supplies are limited both in quality and quantity. Crop residues therefore, remain the only feedstuff available as livestock feed during the dry season. The main nutritional constrain to the use of crop residues as ruminant feed is the rapid decline in quality, slow rate of digestion due to high lignin content and relatively poor nutrient content (Fajemisin et al., 2012). The detrimental effect of the long dry season in arid and semi-arid regions on quantity and quality of feed available to livestock are well documented (Alhassan et al., 1983; Abubakar, 1998; Ben Salem, 2010). Ibeawuchi and Adamu (1990) estimated that as much as $15 \%$ of the animal body weight attained at the end of the previous rainy season could be lost during the following dry season. Efforts to alleviate these constraints and reduce high cost of feeds have been concentrated primarily on harnessing feeds formulated from available, cheap and nutritionally adequate alternatives and/or unconventional feedstuffs of no nutritional value in human diets (Fajemisin et al., 2012; Areegbe et al., 2013). Sugarcane waste is one of such unconventional feedstuffs which is produced in large quantities in the country and could therefore be used to feed livestock after ensiling with urea, poultry litter and soybean meal to enhance nitrogen content and also digestibility. This study therefore aimed at determining the effects of enhancing and ensiling sugarcane waste with urea, soybean meal and poultry litter diets for Yankasa sheep as dry season feed. The objectives of the study was to assess the effect of feeding the diets of ESCW on performance and nutrient digestibility of Yankasa rams.

\section{MATERIALS AND METHODS}

Location and Climate

The study was conducted at the Small Ruminant Unit of the Livestock Teaching and Research Farm, Department of Animal Science, Kano University of Science and Technology, Wudil, Kano State, located in the Sudan Savannah Region of Nigeria. The site is situated between longitude $8^{0} 25^{\prime} \mathrm{E}$ and latitude $12^{0} 58^{\prime} \mathrm{N}$. The area has an average annual rainfall of $890 \mathrm{~mm}$ with a peak in August with an average annual temperature of 38 to $43^{\circ} \mathrm{C}$ and relative humidity of 40 to $51 \%$ (Olofin et al., 2008). There are three distinct seasons recognized in the area viz: dry cold (October to January), dry hot (February to May) and wet (June to September). 
Ensiling Procedures and Experimental Materials Sugarcane waste (SCW) was collected within and around Kano State, cleaned for extraneous materials like stones, iron and polyethene. Soybean grains were obtained from the market, soaked in water overnight and dried by spreading on a concrete floor under sun light. After drying it was milled to produce soybean meal (SBM). Inorganic granulated urea was obtained from market while poultry litter $(\mathrm{PL})$ was obtained from the deep litter poultry production system. The collected SCW, PL and soybean meal were sun dried for the period of 3 days during dry season by thinly spreading on a concrete floor. The dried sugarcane wastes used for the silage were chopped into about 2$3 \mathrm{~cm}$ length using forage chopper for better compaction (Ogunlolu et al., 2010). SCW was ensiled with urea, PL and SBM in proportions as presented in Table 1. The procedure of Roy and Rangnekar (2006) was followed in which $1 \mathrm{~kg}$ urea was dissolved in 15 litres of water and sprinkled on $25 \mathrm{~kg}$ sugarcane waste. Diet T1 (control diet) was air dried for $7-9$ hours every day for about 7 days until it became crispy and bagged while diets T2, T3 and T4 were ensiled for 21 days in a 300 liter capacity water reservoir as silo. Silos filled with weighed materials was covered with polyethene and compressed by human trampling. Four hundred kilograms $(400 \mathrm{~kg})$ of each experimental diet (Table 1) were produced and bagged for the experiment. All basal diets were fed ad-libitum to all the experimental animals according to treatments while concentrate diet with $16.26 \%$ CP was formulated (Table 2) and offered as supplement at $1.5 \%$ body weight to all the experimental animals.

\section{Experimental Animals and Management}

Sixteen (16) male Yankasa rams (mean body weight $25 \mathrm{~kg} \pm 0.46$; aged 8 to 15 months) were purchased from the market and quarantined for two weeks. The rams were managed intensively and group fed with cowpea hay and wheat offal in a cross ventilated pen before the commencement of the experiment. The rams were treated for internal and external parasites with Ivomec $^{\circledR}$ - super at $200 \mu \mathrm{g} / \mathrm{kg}$ body weight subcutaneously before the start of the experiment. Rams were divided into 4 groups of 4 animals each in a Randomized Complete Block Design (RCBD) based on live weight (Steel and Torrie, 1980). Rams were housed in individual pens measuring $2 \mathrm{~m} \times 1 \mathrm{~m}$. The pens were cleaned and disinfected using $\mathrm{Omo}^{\circledR}$ detergent and Moriguard ${ }^{\circledR}$. Water and salt lick were provided ad libitum.

\section{Data Collection}

The experimental animals were weighed individually prior to the commencement of the experiment and subsequently at weekly intervals between 8:00am and 9:00am before being offered feed. Daily records of feed intake were taken throughout the period of the experiment by weighing feed offered and left over the following day. Feed efficiency was calculated as the ratio of the feed intake to weight gain in all the replicates. The feeding trial lasted for twelve weeks which included digestibility trial, consisted two weeks adaptation to fecal collection bags fitted on the first day and one week for fecal sample collection. During the collection period, daily feed intake and total fecal output from each animal were recorded. After thorough mixing, $5 \%$ of the air-dried fecal samples were sampled and oven dried at $60^{\circ} \mathrm{C}$ for determination of digestible nutrients. Fecal apparent digestibility of the nutrients was determined for each diet using standard procedures outlined by AOAC (2005).

\section{Chemical Analysis}

Thoroughly mixed representative samples of the experimental diets, concentrate supplement and faeces were analyzed for dry matter (DM), crude protein (CP), crude fibre (CF), ether extract (EE), ash and nitrogen free extract (NFE) according to AOAC (2005) procedures.

\section{Statistical Analysis}

Data generated were subjected to one way analysis of variance (ANOVA) using RCBD and significant differences between the means were tested by least significant difference (Steel and Torrie, 1980). Differences between the means were considered significant at $5 \%$ probability level $(P<0.05)$. The data were analysed using SAS Statistical package (SAS, 1989).

\section{RESULTS AND DISCUSSION Chemical Composition (\%) of the Experimental Diets}

Table 3 shows the chemical composition of the experimental diets and the concentrate supplement. The DM content varied from $92.12 \%$ in T4 to $94.66 \%$ in T1 while the concentrate diet has DM value of $92.83 \%$. The $\mathrm{CP}$ and $\mathrm{CF}$ values were higher for $\mathrm{T} 3$ (15.30\%, $21.18 \%$, respectively), the concentrate diet had $16.74 \%$ CP. Values for EE varied from $2.99 \%$ in $\mathrm{T} 2$ to $3.57 \%$ in T4 while ash content slightly increased from $8.17 \%$ in T4 to $9.04 \%$ in T2. Highest NFE of $56.87 \%$ was obtained in T3. The reported high DM values in the present study might be attributed to the type of ingredients used in the diets which were all dried materials. The CP levels obtained in the present study for the basal diets were lower than the range 16 - $18 \%$ recommended by Norton (2003) for growing sheep and goats. However, the $14.06-$ $15.30 \%$ CP of the basal diets was above the $6-8 \%$ recommended by NRC (1985) for ruminants in the tropics. Similarly, Gatenby (2002) indicated $10-12 \%$ $\mathrm{CP}$ as the moderate level for ruminant production. Even if there are shortages in the roughage diets, the shortages would probably been compensated by the CP (16.74\%) in the concentrate diet. Therefore, the experimental diets of the current study likely provided adequate nitrogen for the rumen microbes to maximally digest the dietary fibre and thereby generating adequate levels of volatile fatty acids.

\section{Growth Performance Characteristics}

The performance characteristics of the experimental animals are presented in Table 4. There were no significant $(P>0.05)$ differences in all the parameters evaluated but values obtained for T3 and T4 were higher numerically compared to those of T1 (control) and $\mathrm{T} 2$. 
Though no significant $(P>0.05)$ differences were recorded among all the parameters, T4 recorded higher final live weight $(34.00 \mathrm{~kg})$ and average daily gain $(101.19 \mathrm{~g} /$ day). All the animals fed the experimental diets were in a positive weight balance, the positive values obtained for all the treatments suggested that the maintenance requirements of the rams were adequately met by the diets. The weight gains obtained in this study compared to reported values (Fajemisin et al., 2008; Arigbede et al., 2011; Fajemisin et al., 2012) is an indication that treated and ESCW could be used for the feeding of sheep. The results of the present study indicated that, the ADG of $101.19 \mathrm{~g} /$ day obtained for rams in T4 was better than the ADG of $90.58 \mathrm{~g} /$ day reported by Bawala et al. (2008) when they replaced sugarcane tops with Leucaena leucocephala foliage. Roughage and concentrate intakes though not significant $(P>0.05)$ in all the treatments were highest in T4 and least in T1. The high intake of roughage in all the treatments in this study could be as a result of the better quality of the materials (urea, soybean meal and poultry litter) used to treat sugarcane waste which might have aided better intake as it provides a source of nutrients effectively utilized by rumen microbes. Feed to gain ratio was better for T4 (9.55) compared to other treatments. Feed efficiency values were not significant $(P>0.05)$, the values varied from 0.08 in $\mathrm{T} 2$ to 0.11 in $\mathrm{T} 1$ and T4. The feed to gain ratio value for animals in T4 was marginally better than animals on other diets, this observation agreed with the findings of Murthy et al. (1995) when caged layer droppings and poultry litter were fed as supplement to lambs and kids. Feed efficiency was not affected across the treatments, this was an indication that the diets were well accepted by the animals and might probably be attributed to the use of concentrate and basal diet since it is well known fact that concentrate feeding stimulates rumen microbes to function more efficiently (McDonald et al., 1998).

\section{REFERENCES}

AOAC. (2005). Association of Official Analytical Chemists. Official Methods of Analysis $18^{\text {th }}$ Edition AOAC Inc, Arlingon, Virginia USA. 1094pp.

Abubakar, M. M. (1998). Utilisation of unconventional feedstuffs for sustainable livestock production. Inaugural Lecture Series No. 9, delivered at the Abubakar Tafawa Balewa University, Bauchi State, Nigeria, on 30 March 1998.

Adebowale, E. A. (1981). Energy requirement of indigenous and exotic lactating cows in a humid tropical environment. Nigerian Journal of Animal Production. 8:86-96.

Alhassan, W.S.; Ehoche, O.W.; Adu, I.F. and Obilana, A.T. (1983). Crop residue potential of Agricultural Development Projects; Chemical Composition of Crop Residues. National Animal Production Research Institute (NAPRI) Annual Report 1983. Pp 60-62.

Areegbe, A. O., Adegbenjo, A. A., Oni, A. O., Falola, O. O. Adedeji, O. Y. and Saka, A. A. (2013). Effect of agro-industrial By-products as supplements for West African Dwarf sheep on digestibility and

\section{Apparent Nutrients Digestibility (\%)}

Apparent nutrients digestibility of the various nutrients is presented in Table 5 . From the results significant $(P<0.05)$ differences were observed in all the parameters except for ash digestibility. CP digestibility was significantly $(P<0.05)$ higher in T4 $(86.76 \%)$ than in T2, differences between other treatments were not significant $(P>0.05)$. T3 and T4 recorded significantly $(P<0.05)$ higher digestibility values in terms of $D M$, CF, NFE. Ether extract digestibility were significantly $(P<0.05)$ higher for T3 and T4. The digestion coefficients in respect of all the nutrients were moderate, this observation might be due to the solubility of urea, soybean meal and poultry litter as sources of protein and energy. The results were similar to what Fajemisin et al. (2008) obtained when sheep were fed rumen content - poultry droppings mixed diets. It has been reported that maximum dietary CF digestion in the rumen occurs when dietary $\mathrm{CP}$ is between 12 and 16\% (McAllan, 1991). These results indicated that urea, soybean meal and poultry litter could be included in the diet of Yankasa rams for dry season feeding.

\section{CONCLUSION}

The results obtained in the study showed that silages of ESCW enhanced with urea, soybean meal and poultry litter improved the CP content of the diets hence better performance by Yankasa rams. Poultry litter treated sugarcane waste was found to be the best, however all diets furnished enough protein that could meet the nitrogen required for growth and maintenance by the animals. It is therefore, recommended that SCW could be enhanced and ensiled for sheep feeding.

\section{ACKNOWLEDGEMENT}

The authors are grateful to the management of Kano University of Science and Technology, Wudil for providing the funds used for the study. The skilled assistance of the Laboratory Staff of Animal Science Department, Ahmadu Bello University Zaria is acknowledged.

nitrogen balance. In: B. M. Oruwari, J. P. Alawa, U. I. Oji, O. J. Owen and O. S. George (eds.) Animal Agriculture: A Tool for Sustainable Economic Transformation. Proceedings of the $38^{\text {th }}$ Annual Conference and $40^{\text {th }}$ Anniversary of the Nigerian Society for Animal Production (NSAP), $17^{\text {th }}-20^{\text {th }}$ March, held at the Department of Animal Science, Faculty of Agriculture, Rivers State University of Science and Technology, Port Harcourt. Pp $369-371$

Arigbede, O. M., Bolaji, O. J., Dele, P. A., Ojo V. O. A, Olanite, J. A. and Jejeniwa, P. O. (2011). Nutrients intake and digestibility of West African Dwarf rams fed with graded levels of molasses and Enterolobium cyclocarpum seeds based concentrate diets as supplements to Panicum maximum. In: A. A. Adeniji, E. A. Olatunji and E. S. Gana (eds.) Value Re Orientation in Animal Production: A Key to National Food Security and Stable Economy. Proceedings of the $36^{\text {th }}$ Annual Conference of the Nigerian Society for Animal Production (NSAP), $13^{\text {th }}-16^{\text {th }}$ March, held at Merit House/Raw Materials Research and Development Council, Abuja. Pp 519 - 522. 
Bawala, T. O., Aina, A. B. J., Onwuka, C. F. I., Oni, A. O., Adebisi, Y. and Alli, M. A. (2008). Studies on performance of sheep fed sugarcane (Sacchrum officinarum) tops supplemented with varying levels of Leuceana leucocephala foliage. In: O. A Adeyemi, A. M. Ogungbesan, A. O. Dada, O. O. Eniolorunda, H. A. Awojobi, D. B. Oke and J. A. Agunbiade (eds.) Animal Agriculture: Towards millennium Development in Nigeria. Proceedings of the $33^{\text {rd }}$ Annual Conference of the Nigerian Society for Animal Production (NSAP), held at College of Agricultural Sciences, Olabisi Onabanjo University Yewa Campus, Ayetoro, Ogun State. Pp 575-578.

Ben Salem, H. (2010). Nutritional management to improve sheep and goat performances in semi-arid regions. $R$. Bras. Zootec 39: 337-347.

Fajemisin, A. N., Alokan, J. A., Aro, S. O., Olowofeso, O. and Fawolu, T. S. (2008). Nutrient intake, digestibility and weight gain of West African Dwarf sheep fed rumen content - poultry droppings mixed diets. In: O. A Adeyemi, A. M. Ogungbesan, A. O. Dada, O. O. Eniolorunda, H. A. Awojobi, D. B. Oke and J. A. Agunbiade (eds.) Animal Agriculture: Towards millennium Development in Nigeria. Proceedings of the $33^{\text {rd }}$ Annual Conference of the Nigerian Society for Animal Production (NSAP), held at College of Agricultural Sciences, Olabisi Onabanjo University Yewa Campus, Ayetoro, Ogun State. Pp $583-586$.

Fajemisin, A. N., C. M., Fadiyamu, A. A., Fajemisin, A. J. and Alokan, J. A. (2012). Dietary effects of ensiled corncobs treated with or without water, lye and urea on performance of West African Dwarf sheep. In: Akpa, G. N., Dairo, F. A. S., Bawa, G. S., Solomon, I. P., Amaefuele, K. U., Odunsi, A. A., and Ladokon, A. O. (eds.) Agricultural Transformation: Strategies and Policies for Livestock Development in Nigeria. Proceedings of the $17^{\text {th }}$ Annual Conference of the Animal Science Association of Nigeria (ASAN), $9^{\text {th }}-$ $13^{\text {th }}$ September held at International Conference Center opposite Radio House Area 8 Abuja, Nigeria. Pp $575-578$.

Gatenby, R. M. (2002). Sheep. Revised edition. Tropical Agricultural Series. Macmillan Publishers Limited 8pp.

Ibeawuchi, J. I. and Adamu, Y. A. (1990). Effects of various levels of dry Acacia albida pods in concentrate supplement for goats: Growth response and feed intake. Bulletin of Animal Health and Production Africa. 38:219-222

McAllan, A. B. (1991). Sources of nitrogen supplements to maximum cereal crop residue digestion in the rumen In: Galle H. G. C. (Ed.) Production and utilization of lignocellulosics. Elsevier Science Publisher Ltd England pp $375-385$

McDonald, P., Edward, R.A., Greenhalgh, J.F.D. and Morgan, C.A. (1998). Animal Nutrition, $5^{\text {th }}$ Ed, Longman, London.

Murthy, K. S., Reddy, M. R. and Reddy, G. V. N. (1995). Utilization of cage layer droppings and poultry litter feed supplements for lambs and kids. Small Ruminant Research. 16 (3): 221 - 225.

Norton, B.W. (2003). The Nutritive value of tree legumes. In: Gutteridge, R. C., Shelton, H.M. (eds.) Forage tree legumes in Tropical Agriculture. Tropical Grassland Society of Australia Inc., Stlucia Queensland. CAB International pp 192 - 201

NRC (1985). National Research Council. Nutrient requirement of domestic animals. Nutrient requirement of sheep $\left(6^{\text {th }}\right.$ Ed). National Academy of Sciences. Washington D.C. USA.

Ogunlolu, B. T., Jolaosho, A. O., Akinola, T. O. and Aniwe, P. O. (2010). Effects of length of storage and mixture of cassava peel, pineapple residues and guinea grass on mineral content of silage. In: O. J. Babayemi, O. A. Abu and E. O. Ewuola (eds.) Fast - Tracking Animal Agriculture in a Challenged Economy. Proceedings of the $35^{\text {th }}$ Annual Conference of the Nigerian Society for Animal Production (NSAP) $14^{\text {th }}-17^{\text {th }}$ March, held at University Ibadan, Nigeria. Pp 489-490.

Olofin, E. A, Nabegu, A.B, Dambazau A.M. (2008). Wudil Within Kano Region A geographical synthesis, A publication of the Department of Geography, Kano University of Science and Technology, Wudil.

Roy, S. and Rangnekar, D. V. (2006). Farmer adoption of urea treatment of cereal straws for feeding animals in Mithila Milk Shed, India. Livestock Research and Development 18(8).

SAS (1989). Statistical Analysis System SAS/STAT. Guided for Personal Computers. Version 6 Edition, Institute Inc. Cary N.C. USA 967 - 978pp.

Steel, R. G. D. and Torrie, J. H. (1980). Principles and Procedures of Statistics. A Biometrical Approach, $2^{\text {nd }}$ Edition. McGraw - Hill, New York.

Table 1: Proportion (\%) of Sugarcane Waste (SCW) ensiled with Urea, Soybean Meal (SBM) and Poultry Litter (PL) for Yankasa Rams.

\begin{tabular}{lcccll}
\hline Treatments & SCW & Urea & SBM & PL & \\
\hline $\mathbf{T}_{\mathbf{1}}$ (control) & 100 & Urea* & - & - & unensiled \\
$\mathbf{T}_{\mathbf{2}}$ & 100 & Urea* & - & - & Ensiled \\
$\mathbf{T}_{\mathbf{3}}$ & 75 & - & 25 & - & Ensiled \\
$\mathbf{T}_{\mathbf{4}}$ & 75 & - & - & 25 & Ensiled
\end{tabular}

*Urea treatment at $25 \mathrm{~kg}$ sugarcane waste to $1 \mathrm{~kg}$ of urea 
Bajopas Volume 11 Number 1 June, 2018

Table 2: Ingredients composition (\%) of concentrate diet for Yankasa rams

\begin{tabular}{ll}
\hline Ingredients & Inclusion level (\%) \\
\hline Maize & 19 \\
Wheat offal & 33 \\
Soybean meal & 14 \\
Cowpea husk & 33 \\
Salt & 1 \\
TOTAL & 100 \\
Calculated CP (\%) & 16.26 \\
Cost/kg diet (\#) & 68.98 \\
\hline
\end{tabular}

Table 3: Chemical composition of the experimental diets and untreated SCW

\begin{tabular}{|c|c|c|c|c|c|c|}
\hline \multirow[b]{2}{*}{ Constituents (\%) } & \multicolumn{4}{|c|}{ Treatments (diets) } & \multirow[b]{2}{*}{ Concentrate diet } & \multirow[b]{2}{*}{ *USCW } \\
\hline & $\mathbf{T}_{1}$ & $\mathbf{T}_{\mathbf{2}}$ & $\mathbf{T}_{3}$ & $\mathbf{T}_{\mathbf{4}}$ & & \\
\hline DM & 94.66 & 92.78 & 93.53 & 92.12 & 92.83 & 96.18 \\
\hline CP & 14.96 & 14.06 & 15.30 & 15.28 & 16.74 & 1.40 \\
\hline CF & 19.39 & 20.07 & 21.18 & 20.43 & 11.42 & 34.78 \\
\hline EE & 3.03 & 2.99 & 3.08 & 3.57 & 4.05 & 0.009 \\
\hline Ash & 8.78 & 9.04 & 8.66 & 8.17 & 9.81 & 0.04 \\
\hline NFE & 52.98 & 53.75 & 56.87 & 53.41 & 58.56 & 53.77 \\
\hline
\end{tabular}

Table 4: Growth performance of Yankasa rams fed sugarcane waste (SCW) ensiled with urea, soybean meal (SBM) and poultry litter (PL)

\begin{tabular}{lccccc}
\multicolumn{7}{c}{ (SBM) and poultry litter (PL) } & \multicolumn{7}{c}{ Treatments (diets) } & LSD \\
\cline { 2 - 5 } Parameters & $\mathbf{T}_{\mathbf{1}}$ & $\mathbf{T}_{\mathbf{2}}$ & $\mathbf{T}_{\mathbf{3}}$ & $\mathbf{T}_{\mathbf{4}}$ & 7.409 \\
\hline Mean initial body weight (kg) & 25.25 & 25.50 & 25.25 & 25.50 & 6.926 \\
Mean final body weight (kg) & 31.75 & 30.75 & 31.50 & 34.00 & 3.253 \\
Average weight gain (kg) & 6.50 & 5.25 & 6.25 & 8.50 & 38.726 \\
Average daily weight gain (g/day) & 77.38 & 62.50 & 74.41 & 101.19 & 186.440 \\
Roughage intake (g/day) & 431.70 & 433.07 & 465.80 & 498.63 & 106.330 \\
Concentrate intake(g/day) & 376.94 & 379.25 & 404.35 & 409.06 & 264.46 \\
Total feed intake (g/day) & 808.60 & 812.30 & 870.10 & 907.70 & 5.677 \\
Feed conversion ratio & 11.44 & 13.54 & 12.07 & 9.55 & 0.503 \\
Feed efficiency & 0.11 & 0.08 & 0.09 & 0.11 & 22.146 \\
Growth rate (\%) & 28.10 & 21.11 & 24.51 & 36.64 & 0.375 \\
DMI as \% Body Weight & 2.37 & 2.44 & 2.51 & 2.46 & 0.323 \\
Protein efficiency & 0.66 & 0.52 & 0.53 & 0.70 &
\end{tabular}

A (100\%SCW+urea unensiled), B (100\%SCW+urea ensiled), C (75\%SCW+SBM ensiled), B (75\%SCW+PL ensiled)

Table 5: Apparent Nutrients Digestibility (\%) by Yankasa Rams fed Sugarcane Waste (SCW) ensiled with Urea, Soybean Meal (SBM) and Poultry Litter (PL)

\begin{tabular}{|c|c|c|c|c|c|c|}
\hline \multirow[t]{2}{*}{ Parameters } & \multicolumn{4}{|c|}{ Treatments } & \multirow[b]{2}{*}{ LSD } & \multirow[b]{2}{*}{$\pm \mathrm{SE}$} \\
\hline & $\mathbf{A}$ & B & $\mathbf{C}$ & D & & \\
\hline $\mathrm{DM}$ & $70.10^{b}$ & $68.85^{b}$ & $77.53^{a}$ & $78.35^{\mathrm{a}}$ & 6.851 & 2.97 \\
\hline $\mathrm{CP}$ & $80.89^{a b}$ & $80.63^{b}$ & $86.30^{\mathrm{ab}}$ & $86.76^{a}$ & 5.878 & 2.55 \\
\hline CF & $70.91^{\mathrm{b}}$ & $71.10^{\mathrm{b}}$ & $84.63^{a}$ & $84.40^{\mathrm{a}}$ & 8.989 & 3.90 \\
\hline $\mathrm{EE}$ & $72.79^{b}$ & $76.10^{\mathrm{ab}}$ & $83.94^{\mathrm{a}}$ & $83.88^{\mathrm{a}}$ & 10.978 & 4.76 \\
\hline Ash & 71.22 & 70.16 & 76.05 & 75.99 & 6.939 & 3.01 \\
\hline NFE & $70.13^{b}$ & $70.67^{b}$ & $78.70^{\mathrm{a}}$ & $79.42^{\mathrm{a}}$ & 6.113 & 2.65 \\
\hline
\end{tabular}

